\title{
WestVirginiaUniversity
}

THE RESEARCH REPOSITORY @ WVU

Volume 40 | Issue 2

Article 17

February 1934

\section{The Interpretation of Treaties by Judicial Tribunals}

Keener C. Frazer

University of North Carolina

Follow this and additional works at: https://researchrepository.wvu.edu/wvlr

Part of the Military, War, and Peace Commons

\section{Recommended Citation}

Keener C. Frazer, The Interpretation of Treaties by Judicial Tribunals, 40 W. Va. L. Rev. (1934).

Available at: https://researchrepository.wvu.edu/wvlr/vol40/iss2/17

This Book Review is brought to you for free and open access by the WVU College of Law at The Research Repository @ WVU. It has been accepted for inclusion in West Virginia Law Review by an authorized editor of The Research Repository @ WVU. For more information, please contact ian.harmon@mail.wvu.edu. 


\section{BOOK REVIEWS}

The Interpretation of Treaties by Judictar Tribunals. By Yi-Ting Chang, Ph. D. New York: The Columbia University Press, 1933. Pp. 196.

The author announces the purpose of his work to be to determine by case examination the extent to which treaties have been interpreted according to certain so-called classical canons as stated by great publicists and as proclaimed by tribunals. In pursuance of this purpose the author treats of certain elements in this problem as "clear meaning", "doubtful meaning", "The admissibility of preparatory work", "versions in different languages", and the so-called "rule of liberal construction" employed by the United States Supreme Court.

The interpretation of a treaty in the light. of its "clear meaning" is, in the opinion of the author, a practice which more nearly approaches a rule than any other here considered. On the other hand where the text of the treaty is of "doubtful meaning" the courts have yielded to the consideration of the sacrifice involved and have sought for external evidence from numerous sources. Where the "manifest purpose" of the parties to the treaty has been discernible the courts have uniformly adopted this "manifest purpose" as a guide in reaching a decision.

Dr. Chang's discussion of the "admissibility of preparatory work" to prove the purpose of the contracting parties is most interesting and instructive. "The admissibility of preparatory work" like other subjects here treated, is largely discussed in the light of the practice followed by the Permanent Court of International Justice which appears to be to give effect to the objects had in view by the parties to the contract. It is pointed out that the experience of this Court has found no conflict between the "clear meaning" of the text and the objects contemplated by the framers of the treaty. Conflict may appear where a text appears in more than one language. In such cases the Courts have generally adhered to the more restricted meaning. The "rule of liberal construction" which has been said to be employed by the United States Supreme Court, the author declares to be little more than that treaties be interpreted in good faith.

The author concludes that classical canons and the pronouncements of tribunals concerning them, which have been called rules 
of interpretation, have had little effect in the interpretation of treaties, and that the task of interpretation has been, and is, "simply to discover and ascertain, with the aid of various sources of evidence, the sense in which the contracting parties actually employed particular terms in a treaty".

Dr. Chang has made a valuable and scholarly contribution to the literature of this confused subject, and he has, to a certain extent, succeeded in establishing a degree of order. The title of his work is perhaps too inclusive for he has, in fact, largely studied the decisions of The Permanent Court of International Justice and those of certain international arbitral commissions and the Supreme Court of the United States.

-Kegner C. Frazer.

University of North Carolina.

The lake Cargo Coal Rate Controversy. A Study in Governmental Adjustment of a Sectional Dispute. By Harvey C. Mansfield. New York: Columbia University Press. 1932. Pp. 273.

The Lake Cargo Coal Rate Controversy is a significant work. It has a wider application than one might at first suppose. The principles involved in the contest between coal operators of the northern Ohio and Pittsburgh district on the one side and the operators in the southern district comprising the coal fields of West Virginia and Kentucky on the other, underlie the fixing of rates for California fruit or the granting of a differential in favor of New Orleans over other Gulf ports in the export cotton trade. It is an instance of the federal government attempting to settle an economic problem. It shows the difficulties that present themselves when the government undertakes through any of its agencies to readjust economic advantages or disadvantages of one section of the country over another. Incidentally it emphasizes the difficulties of rate-making.

The Lake Cargo controversy arose in 1909. Prior to that time the northem operators had enjoyed a monopoly of the coal market of the northwest. The coal destined for that area is shipped by rail to the lake ports of Ohio and thence carried by vessels used in bringing iron ore from the northwest. Such 